根拠に基づく医療（EBM）をサポートするための実験技術の開発と評価系の確立

田頭 秀 章, ${ }^{*}, a$ 小堀 宅 郎 $b$

\title{
Development of Experimental Techniques and Evaluation to Support Evidence-Based Medicine (EBM)
}

\author{
Hideaki Tagashira ${ }^{*, a}$ and Takuro Kobori ${ }^{b}$ \\ aDepartment of Pharmacology, Graduate School of Pharmaceutical Sciences, Tohoku University; \\ 6-3 Aramaki-Aoba, Aoba-ku, Sendai 980-8578, Japan: and bepartment of Clinical \\ Pharmacy, School of Pharmaceutical Sciences, Kobe Gakuin University; \\ 1-1-3 Minatojima, Chuo-ku, Kobe 650-8586, Japan.
}

わが国は，急激な高齢化が進行し，医療の面でも 重大な社会問題に直面しています。医療の質を高め るために，薬学の果たす役割は多大であり，患者に 対する QOL の改善と治療法の選択に貢献する根拠 に基づく医療 (evidence-based medicine; EBM) の 確立が不可欠と考えられます。本シンポジウムで は, 田頭秀章（東北大学）と小堀宅郎（神戸学院大 学）がオーガナイザーを務めて, 比留間 航（福岡 大学), Panot Tangsucharit (岡山大学), 西中 崇 (神戸学院大学), 矢吹 悌 (東北大学), 河原 遼 (熊本大学) の, 薬物療法に係わる実験技術の開発 を精力的に行っている 5 名の大学院生により, 解析 手法において既存の薬効解析にとらわれずに，動物 個体, 組織, 細胞レベルで新しい評価系の確立に取 り組んでいる研究について紹介しました。また,

EBM をサポートする確実な研究成果を得るための 多面的な実験技術改良の現状と課題について紹介し ました。今回取り上げた疾患の治療薬や開発中の化 合物は, 治療満足度が得られていない薬や疾患領域
であり，薬効を評価する実験系を確立することが重 要です。各シンポジストはユニークな薬効評価法を 用いて様々な角度から薬物による生体反応, 薬理作 用をとらえることに着目して研究を進めていたので 非常に有意義なものとなりました，さらに，シンポ ジウムでは積極的な異分野間での意見交換を通じ て，若手研究者の人的交流もできたことから，将来 の創薬研究の発展に寄与し得るシンポジウムとなり ました。本シンポジウム及び本誌上シンポジウム が, 若手研究者による薬学会の活性化や新しいメ力 ニズムを有する新薬の創薬に貢献することを期待し ます。

最後に，本誌上シンポジウムの開催及び執筆にあ たり貴重な機会を与えて頂きました日本薬学会第 132 年会組織委員長 松田 彰 教授, 並びにご指導 頂きました日本薬学会役員の皆様, そして今回ご参 加頂きました各大学の先生方並びにご尽力頂きまし た関係者各位に，この場をお借りして厚く御礼申し 上げます。

\footnotetext{
$a$ 東北大学大学院薬学研究科薬理学分野 (T980-8578 仙台市青葉区荒巻字青葉 6-3), $b$ 神戸学院大学薬学部 臨床薬学研究室 (T650-8586 神戸市中央区港島 1-1-3) *e-mail: b1yd1021@s.tohoku.ac.jp 日本薬学会第 132 年会シンポジウム S28 序文
} 